\title{
Reply \\ Reply to von Bünau et al. Comment on "Depoorter, L.; Vandenplas, Y. Probiotics in Pediatrics. A Review and Practical Guide. Nutrients 2021, 13, 2176"
}

\author{
Yvan Vandenplas* (D) and Leontien Depoorter
}

check for

updates

Citation: Vandenplas, Y.; Depoorter,

L. Reply to von Bünau et al.

Comment on "Depoorter, L.;

Vandenplas, Y. Probiotics in

Pediatrics. A Review and Practical

Guide. Nutrients 2021, 13, 2176".

Nutrients 2022, 14, 725. https://

doi.org/10.3390/nu14040725

Academic Editor: Silvia Scaglioni

Received: 5 January 2022

Accepted: 11 January 2022

Published: 9 February 2022

Publisher's Note: MDPI stays neutral with regard to jurisdictional claims in published maps and institutional affiliations.

Copyright: (c) 2022 by the authors. Licensee MDPI, Basel, Switzerland. This article is an open access article distributed under the terms and conditions of the Creative Commons Attribution (CC BY) license (https:// creativecommons.org/licenses/by/ $4.0 /)$.
KidZ Health Castle, UZ Brussel, Vrije Universiteit Brussel, 1090 Brussels, Belgium; leontien.depoorter@uzbrussel.be

* Correspondence: yvan.vandenplas@uzbrussel.be

We agree with Prof. Stange and Erhardt for their comment on our paper on Probiotics in Pediatrics [1], regarding our statement "In adults, several studies showed a beneficial effect of E. coli Nissle 1917 compared to standard treatment with mesalazine alone in maintaining remission of the disease [1,2]. Again, these results were not confirmed by any RCT [3]." As Prof. Stange and Erhardt claim, we reported that there are trials with E. coli Nissle 1917 in adults. However, there are-to the best of our knowledge-no randomized controlled trials in children. Therefore, we wrote "Again, these studies were not confirmed by any randomized controlled trial" (in children, since the manuscript is about probiotics in pediatrics). So, while there is some evidence in adults, there are no data in pediatrics.

Funding: This research received no external funding.

Conflicts of Interest: The authors declare no conflict of interest.

\section{References}

1. Depoorter, L.; Vandenplas, Y. Probiotics in Pediatrics. A Review and Practical Guide. Nutrients 2021, 13, 2176. [CrossRef] [PubMed]

2. Scaldaferri, F.; Gerardi, V.; Mangiola, F.; Lopetuso, L.R.; Pizzoferrato, M.; Petito, V.; Papa, A.; Stojanovic, J.; Poscia, A.; Cammarota, G.; et al. Role and Mechanisms of Action of Escherichia coli Nissle 1917 in the Maintenance of Remission in Ulcerative Colitis Patients: An Update. World J. Gastroenterol. 2016, 22, 5505-5511. [CrossRef] [PubMed]

3. Petersen, A.M.; Mirsepasi, H.; Halkjær, S.I.; Mortensen, E.M.; Nordgaard-Lassen, I.; Krogfelt, K.A. Ciprofloxacin and Probiotic Escherichia coli Nissle Add-on Treatment in Active Ulcerative Colitis: A Double-Blind Randomized Placebo Controlled Clinical Trial. J. Crohn's Colitis 2014, 8, 1498-1505. [CrossRef] [PubMed] 